\title{
Comparative assessment of fetomaternal outcome in twin pregnancy with singleton pregnancy at tertiary care centre
}

\section{Divya Gupta, Premlata Mital*, Bhanwar Singh Meena, Devendra Benwal, Saumya, Sunita Singhal, Richa Ainani}

Department of Obstetrics and Gynecology, S.M.S. Medical College, Jaipur, Rajasthan, India

Received: 16 March 2017

Accepted: 21 April 2017

*Correspondence:

Dr. Premlata Mital,

E-mail: drpremlatamital@gmail.com

Copyright: (c) the author(s), publisher and licensee Medip Academy. This is an open-access article distributed under the terms of the Creative Commons Attribution Non-Commercial License, which permits unrestricted non-commercial use, distribution, and reproduction in any medium, provided the original work is properly cited.

\section{ABSTRACT}

Background: Multiple pregnancy remains one of the highest risk situations for the mother, foetus and neonate despite recent advances in obstetrics, perinatal and neonatal care. Twin pregnancies have increased rates of obstetric and perinatal complications compared to singletons Objective of present study was comparative assessment of fetomaternal outcome in twin pregnancy with singleton pregnancy in Obstetrics and Gynaecology Department of S.M.S. Medical College, Jaipur.

Methods: This was a hospital based, prospective observational study done in the Department of Obstetrics and Gynaecology. S.M.S. Medical College, Jaipur from April 2015 to March 2016. 150 women with twin pregnancy and 150 women with singleton pregnancies at gestation age of 28 weeks and above coming for delivery and consented for the study were included in the study. Women with chronic medical disorder or chronic hypertension were excluded from the study. Maternal and neonatal outcome recorded and analysed.

Results: Occurrence of twin in our study was $2.82 \%$. Risk of preterm labour was about nine times higher in twin pregnancies than the singleton (OR: $2.74,95 \% \mathrm{CI} ; 1.4494-5.1884, \mathrm{P}$ value 0.001 ). The risk of premature rupture of membrane was increased by 2.74 times in twin pregnancies (OR:2.74; 95\% CI: 1.4494-5.1884, $\mathrm{p}$ value .001). There was 3-time increased risk of malpresentation (OR 3.14; CI:1.7184-5.7480, p value .00002) and 2.28 times increase in hypertensive disorder (OR 2.28; 95\% CI: 1.0727-4.8823, p value .03) in twin pregnancies. The risk of asphyxia and septicaemia was 2.5 times more in twins.

Conclusions: Twin pregnancy is a high-risk pregnancy with more complications in mother and foetus and is a great challenge for obstetrician. So, it should be managed carefully at tertiary care centre to reduce the maternal and perinatal mortality and morbidity.

Keywords: Fetomaternal outcome, High-risk pregnancy, Singleton pregnancy, Twin pregnancy

\section{INTRODUCTION}

Multiple pregnancy remains one of the highest risk situations for the mother, foetus and neonate despite recent advances in obstetrics, perinatal and neonatal care. Twin pregnancies have increased rates of obstetric and perinatal complications compared to singletons such as risk of miscarriage, pre-eclampsia, post-partum haemorrhage, preterm labour, iron and folic acid deficiency anemia, polyhydramnios, discordant foetal growth, abnormal vascular communications, foetal malformations, cord complication, still births and increased rate of caesarean section. ${ }^{1}$ Although twins occur in approximate 1 in 80 pregnancy, they account for $12.2 \%$ of preterm births and $15.4 \%$ neonatal death. 
Compared to singleton pregnancy the perinatal mortality, morbidity and long term neurological developmental disability are also increased 5-10-fold in twin pregnancy. ${ }^{2}$

Multiple pregnancies in low-resource settings pose higher feto-maternal risks due to a scarcity of human and material resources, which translate into insufficient care during pregnancy and delivery.

The millennium Development Goals number four and five calls for the world to reduce child morbidity and mortality as well as to improve maternal health by reducing maternal mortality and morbidities especially in developing countries.

The fact that multiple pregnancy puts mothers at risk of miscarriage, pre-eclampsia (which is 2-3 times more common in multiple than singleton pregnancy), iron and folic acid deficiency anaemia, polyhydramnios, preterm labour, and increased rate of caesarean section, there is a need to determine the perinatal and maternal complications of multiple pregnancies in our setting so that we can get the pattern of complication under this setting where resource is poor. It might help in assisting in the management, counseling of women with multiple pregnancies on the possible outcomes and early interventions to prevent death of mothers of multiple pregnancy and their babies due to complications. Keeping this in mind the present study was done to determine risk of fetometernal complications in twin pregnancy in comparison to singleton pregnancy.

\section{METHODS}

This was a hospital based, prospective observational study done in the Department of Obstetrics and Gynaecology, S.M.S. Medical College, Jaipur from April 2015 to March 2016. All women with twin pregnancy and singleton pregnancies at gestation age of 28 weeks and above coming for delivery and consented for the study were included in the study. Women with chronic medical disorder or chronic hypertension were excluded from the study.

Sample size was calculated as 144 subjects in each group at $80 \%$ study power and alpha error of 0.05 assuming expected odds ratio of 2.6 for preeclampsia and expected proportion in control of preeclampsia of $94 \%$. Sample size required without continuity correction was 144 cases. It was rounded off to 150 subjects in each group. The gestation age was determined by either date from the first day of the last normal menstrual period or by extrapolations from early obstetric ultrasound or first visit found on the antenatal card when reporting in labour ward. For each twin pregnancy woman with singleton pregnancy was enrolled after obtaining written informed consent.

All the necessary information regarding demographic data, clinical findings, obstetric scan if present, and outcomes of each participant and their babies were collected during admission and during the course of management by using data collecting form. Patients (both mothers and babies) were followed within seven days. Those patients who were discharged early were asked to leave their mobile phone numbers or attend Obstetrics and Gynecology Department at day seven.

Data entry was done using Microsoft Excel sheet. computer software. Numeric values were expressed as mean and standard deviations. One way analysis of variance was performed for comparing means of groups. Chi-square test or Tukey HSD Post-hoc Test was done to calculate $\mathrm{p}$ value. In analysis, a p-value of less than 0.05 was considered statistically significant. The odds ratio with $95 \%$ confidence interval for maternal and fetal outcome between twin pregnancy and singleton was calculated.

\section{RESULTS}

Total number of deliveries during study period was 10649 and total no of twin delivery with gestational age of 28 weeks or more was 300 so occurrence of twin is $28.2 / 1000$ live birth $(2.82 \%)$.

Various complications observed in the mother are shown in Table 1. The risk of preterm labour was about nine times higher in twin pregnancies than the singleton (OR: $2.74,95 \% \mathrm{CI} ; 1.4494-5.1884, \mathrm{P}$ value 0.001$)$. The risk of premature rupture of membrane was increased by 2.74 times in twin pregnancies (OR:2.74; 95\% CI: 1.44945.1884, $\mathrm{p}$ value 0.001$)$. The risk of APH was 1.36 times more (OR 1.36; 95\% CI 0.5563-3.3360) and PPH was 2.75 times more than the singleton pregnancies. There was 3 time increased risk of malpresentation (OR 3.14; CI:1.7184-5.7480, p value 0.00002) and 2.28 times increase in hypertensive disorder (OR 2.28; 95\% CI: $1.0727-4.8823, \mathrm{p}$ value 0.03 ) in twin pregnancies. The risk of delivery in twin pregnancy via caesarean section was 1.76 times that of singleton pregnancies (OR 1.76; 95\% CI: $1.0990-2.8053$, p value 0.01$)$. The risk of IUGR was 1.79 times (OR 1.79; 95\% CI 0.9636-3.3478, p value 0.06 ) and risk of developing anaemia was 1.36 times more in twin pregnancy than that of singleton pregnancy. The risk of developing polyhydramnios was 2.55 times more in twin pregnancy (OR 2.55; 95\% CI 0.487213.3636). Table 2 shows risk of various neonatal morbidities in twin pregnancy. Risk of a twin pregnancy being delivered prematurely was about 2 times that of a singleton (OR 2.0073; 95\% CI: 1.0509-3.8342). The risk of asphyxia was 2.5 times that of a singleton (OR $2.58 ; 95 \%$ CI $0.7348-9.0510)$. The risk of jaundice was same in twins and singleton babies (OR 1.00;95\% CI $0.0899-11.1177)$. Risk of developing septicemia in twins was 2.5 times that of a singleton (OR 2.53; 95\% CI 0.2924-21.8128) and the risk of congenital malformation in twin babies was 1.5 times than that of singleton babies (OR1.51; 95\% CI 0.0610-37.2299). 
Table 1: Comparison of maternal outcomes in twin and singleton deliveries.

\begin{tabular}{|c|c|c|c|c|c|c|}
\hline \multirow{2}{*}{ Outcomes } & \multicolumn{2}{|c|}{ Twin $(n=150)$} & \multicolumn{2}{|c|}{ Singleton $(n=150)$} & \multirow{2}{*}{ OR $(95 \%$ CI $)$} & \multirow{2}{*}{$\mathbf{P}$ value } \\
\hline & No. & $\%$ & No. & $\%$ & & \\
\hline \multicolumn{6}{|l|}{ PROM } & \multirow{3}{*}{$\begin{array}{l}0.001 \\
\text { significant }\end{array}$} \\
\hline Yes & 37 & 24.7 & 16 & 10.7 & \multirow{2}{*}{$\begin{array}{l}2.74 \\
(1.4494-5.1884)\end{array}$} & \\
\hline No & 113 & 75.3 & 134 & 89.3 & & \\
\hline \multicolumn{6}{|l|}{ Preterm labour } & \multirow{3}{*}{$\begin{array}{l}0.0001 \\
\text { significant }\end{array}$} \\
\hline Yes & 94 & 62.7 & 24 & 16.0 & \multirow{2}{*}{$\begin{array}{l}8.8 \\
(5.0959-15.2399)\end{array}$} & \\
\hline No & 56 & 37.3 & 126 & 84.0 & & \\
\hline \multicolumn{6}{|l|}{ APH } & \multirow{3}{*}{$\begin{array}{l}0.49 \\
\text { not significant }\end{array}$} \\
\hline Yes & 12 & 8.0 & 9 & 6.0 & \multirow{2}{*}{$\begin{array}{l}1.36 \\
(0.5563-3.3360)\end{array}$} & \\
\hline No & 138 & 92.0 & 141 & 94.0 & & \\
\hline \multicolumn{6}{|l|}{ IUGR } & \multirow{3}{*}{$\begin{array}{l}0.06 \\
\text { not significant }\end{array}$} \\
\hline Yes & 31 & 20.7 & 19 & 12.7 & \multirow{2}{*}{$\begin{array}{l}1.79 \\
(0.9636-3.3478)\end{array}$} & \\
\hline No & 119 & 79.3 & 131 & 87.3 & & \\
\hline \multicolumn{6}{|l|}{ PPH } & \multirow{3}{*}{$\begin{array}{l}0.06 \\
\text { not significant }\end{array}$} \\
\hline Yes & 13 & 8.7 & 5 & 3.3 & \multirow{2}{*}{$\begin{array}{l}2.75 \\
(0.9557-7.9232)\end{array}$} & \\
\hline No & 137 & 91.3 & 145 & 97.7 & & \\
\hline \multicolumn{6}{|c|}{ Hypertensive disorders of pregnancy } & \multirow{3}{*}{$\begin{array}{l}0.03 \\
\text { significant }\end{array}$} \\
\hline Yes & 23 & 15.3 & 11 & 7.3 & \multirow{3}{*}{$\begin{array}{l}2.28 \\
(1.0727-4.8823)\end{array}$} & \\
\hline No & 127 & 84.7 & 139 & 92.7 & & \\
\hline \multicolumn{5}{|l|}{ Polyhydramnios } & & \multirow{3}{*}{$\begin{array}{l}0.26 \\
\text { not significant }\end{array}$} \\
\hline Yes & 5 & 3.3 & 2 & 1.3 & \multirow{3}{*}{$\begin{array}{l}2.55 \\
(0.4872-13.3636)\end{array}$} & \\
\hline No & 145 & 97.7 & 148 & 98.7 & & \\
\hline \multicolumn{5}{|l|}{ Anemia } & & \multirow{3}{*}{$\begin{array}{l}0.49 \\
\text { not significant }\end{array}$} \\
\hline Yes & 12 & 8.0 & 9 & 6.0 & \multirow{3}{*}{$\begin{array}{l}1.36 \\
(0.5563-3.3360)\end{array}$} & \\
\hline No & 138 & 92.0 & 141 & 94.0 & & \\
\hline \multicolumn{5}{|l|}{ Caesarean section } & & \\
\hline Yes & 69 & 46.0 & 50 & 33.3 & 1.76 & $\begin{array}{l}0.01 \\
\text { sionificant }\end{array}$ \\
\hline No & 81 & 54.0 & 100 & 66.7 & $(1.0990-2.8053)$ & \\
\hline Malpresentation & & & & & & \\
\hline Yes & 45 & 30.0 & 18 & 12.0 & 3.14 & $\begin{array}{l}0.0002 \\
\text { sionificant }\end{array}$ \\
\hline No & 105 & 70.0 & 132 & 88.0 & $(1.7184-5.7480)$ & \\
\hline
\end{tabular}

Table 2: Comparison of neonatal morbidity in twin and singleton.

\begin{tabular}{|c|c|c|c|c|c|c|}
\hline \multirow{2}{*}{ Causes of neonatal morbidity } & \multicolumn{2}{|c|}{ Twin $(n=300)$} & \multicolumn{2}{|c|}{ Singleton $(\mathrm{n}=150)$} & \multirow{2}{*}{ OR $(95 \% \mathrm{CI})$} & \multirow{2}{*}{ P value } \\
\hline & No. & $\%$ & No. & $\%$ & & \\
\hline \multicolumn{5}{|l|}{ Asphyxia } & \multirow{3}{*}{$\begin{array}{l}2.58 \\
(0.7348-9.0510)\end{array}$} & \multirow{3}{*}{$\begin{array}{l}0.13 \\
\text { not significant }\end{array}$} \\
\hline Yes & 15 & 5.0 & 3 & 2.0 & & \\
\hline No & 285 & 95.0 & 147 & 98.0 & & \\
\hline \multicolumn{5}{|l|}{ Prematurity } & \multirow{3}{*}{$\begin{array}{l}2.0073 \\
(1.0509-3.8342)\end{array}$} & \multirow{3}{*}{$\begin{array}{l}0.03 \\
\text { significant }\end{array}$} \\
\hline Yes & 48 & 16.0 & 13 & 8.7 & & \\
\hline No & 252 & 84.0 & 237 & 91.3 & & \\
\hline \multicolumn{5}{|l|}{ Jaundice } & \multirow{3}{*}{$\begin{array}{l}1.25 \\
(0.2405-6.5419)\end{array}$} & \multirow{3}{*}{$\begin{array}{l}0.78 \\
\text { not significant }\end{array}$} \\
\hline Yes & 5 & 1.7 & 2 & 1.3 & & \\
\hline No & 295 & 98.3 & 148 & 98.7 & & \\
\hline \multicolumn{5}{|l|}{ Respiratory Distress } & \multirow{3}{*}{$\begin{array}{l}1.98 \\
(0.7112-5.5285)\end{array}$} & \multirow{3}{*}{$\begin{array}{l}0.19 \\
\text { not significant }\end{array}$} \\
\hline Yes & 16 & 5.3 & 5 & 3.3 & & \\
\hline No & 284 & 94.7 & 145 & 96.7 & & \\
\hline \multicolumn{5}{|l|}{ Septicemia } & \multirow{3}{*}{$\begin{array}{l}2.03 \\
(0.4251-9.6682)\end{array}$} & \multirow{3}{*}{$\begin{array}{l}0.37 \\
\text { not significant }\end{array}$} \\
\hline Yes & 8 & 2.7 & 2 & 1.3 & & \\
\hline No & 292 & 97.3 & 148 & 98.7 & & \\
\hline \multicolumn{5}{|l|}{ Unexplained } & \multirow{3}{*}{$\begin{array}{l}2.53 \\
(0.2924-21.8128)\end{array}$} & \multirow{3}{*}{$\begin{array}{l}0.3 \\
\text { not significant }\end{array}$} \\
\hline Yes & 5 & 1.6 & 1 & 0.7 & & \\
\hline No & 295 & 98.4 & 149 & 99.3 & & \\
\hline \multicolumn{5}{|l|}{ Congenital malformation } & \multirow{3}{*}{$\begin{array}{l}1.51 \\
(0.0610-37.2299)\end{array}$} & \multirow{3}{*}{$\begin{array}{l}0.8 \\
\text { not significant }\end{array}$} \\
\hline Yes & 1 & 0.3 & 0 & 0 & & \\
\hline No & 299 & 99.7 & 150 & 100 & & \\
\hline
\end{tabular}


Prematurity was the commonest cause of perinatal mortatlity in twins and risk was about 4 times more than singleton (OR 3.69, CI 1.0822-12.5692, p value .03). Other causes of mortality include asphyxia (OR $1.31 ; 95 \%$ CI $0.4594-3.7559)$, jaundice $(0.6 \%$ OR $1.00 ; 95 \%$ CI
0.0899-11.1177), respiratory distress (1.3\% OR .66; 95\% CI:0.1463-2.9974), septicemia (1.7\% OR 2.53; 95\% CI 0.2924-1.8128), unexplained (OR 2.53; 95\% CI 0.292421.8128 ) and Congenital malformation (OR 1.51; $95 \% \mathrm{CI}$ $0.0610-37.2299)$. The risk of these factors were 1.5 to 2.5 times more in twins than singleton (Table 3).

Table 3: Comparison of causes of perinatal death in twin and singleton deliveries.

\begin{tabular}{|c|c|c|c|c|c|c|}
\hline \multirow{2}{*}{ Causes of neonatal death } & \multicolumn{2}{|c|}{ Twin $(\mathrm{n}=300)$} & \multicolumn{2}{|c|}{ Singleton $(\mathrm{n}=150)$} & \multirow{2}{*}{ OR $(95 \%$ CI) } & \multirow{2}{*}{ P value } \\
\hline & No. & $\%$ & No. & $\%$ & & \\
\hline \multicolumn{5}{|l|}{ Asphyxia } & \multirow{3}{*}{$\begin{array}{l}1.31 \\
(0.4594-3.7559)\end{array}$} & \multirow{3}{*}{$\begin{array}{l}0.61 \\
\text { not significant }\end{array}$} \\
\hline Yes & 13 & 4.3 & 5 & 3.3 & & \\
\hline No & 287 & 95.7 & 145 & 96.7 & & \\
\hline \multicolumn{5}{|l|}{ Prematurity } & \multirow{3}{*}{$\begin{array}{l}3.69 \\
(1.0822-12.5692)\end{array}$} & \multirow{3}{*}{$\begin{array}{l}0.03 \\
\text { significant }\end{array}$} \\
\hline Yes & 21 & 7.0 & 3 & 2.0 & & \\
\hline No & 279 & 93.0 & 147 & 98.0 & & \\
\hline \multicolumn{5}{|l|}{ Jaundice } & \multirow{3}{*}{$\begin{array}{l}1.00 \\
(0.0899-11.1177)\end{array}$} & \multirow{3}{*}{$\begin{array}{l}1.0 \\
\text { not significan }\end{array}$} \\
\hline Yes & 2 & 0.6 & 1 & 0.7 & & \\
\hline No & 298 & 99.6 & 149 & 99.3 & & \\
\hline \multicolumn{5}{|l|}{ Respiratory distress } & \multirow{3}{*}{$\begin{array}{l}0.66 \\
(0.1463-2.9974)\end{array}$} & \multirow{3}{*}{$\begin{array}{l}0.59 \\
\text { not significant }\end{array}$} \\
\hline Yes & 4 & 1.3 & 3 & 2.0 & & \\
\hline No & 296 & 98.7 & 147 & 98.0 & & \\
\hline \multicolumn{5}{|l|}{ Septicemia } & \multirow{3}{*}{$2.53(0.2924-21.8128)$} & \multirow{3}{*}{$\begin{array}{l}0.39 \\
\text { not significant }\end{array}$} \\
\hline Yes & 5 & 1.7 & 1 & 0.7 & & \\
\hline No & 295 & 98.3 & 149 & 99.3 & & \\
\hline \multicolumn{5}{|l|}{ Unexplained } & \multirow{3}{*}{$\begin{array}{l}2.53 \\
(0.2924-21.8128)\end{array}$} & \multirow{3}{*}{$\begin{array}{l}0.3 \\
\text { not significant }\end{array}$} \\
\hline Yes & 5 & 1.6 & 1 & 0.7 & & \\
\hline No & 297 & 98.4 & 149 & 99.3 & & \\
\hline \multicolumn{5}{|l|}{ Congenital Malformation } & \multirow{3}{*}{$\begin{array}{l}1.51 \\
(0.0610-37.2299)\end{array}$} & \multirow{3}{*}{$\begin{array}{l}0.8 \\
\text { not significant }\end{array}$} \\
\hline Yes & 1 & 0.3 & 0 & D & & \\
\hline No & 299 & 99.7 & 150 & 100.0 & & \\
\hline
\end{tabular}

\section{DISCUSSION}

In present study, authors compared fetomaternal outcomes between twin and singleton pregnancy. It was observed that risk of preterm delivery, APH, PPH, anemia. hypertensive disorders of pregnancy, cesarean delivery, prematurity, asphyxia, jaundice and congenital malformations were more in mother and newborn of twin pregnancy as compared to singleton pregnancy. The occurrence of twins in present study (28.2/1000births) was consistent with previous studies done by Adamson $\mathrm{H}$, Musili FKJ, Peter B. ${ }^{3-5}$ it was lower compared to that reported by Nigerian investigators Olusanya BO, Rizwan $\mathrm{N}$ et al and Abasiattai AM, Iyiola OA who found the twinning rates between $26.0-46.5$ per 1000 births. ${ }^{6-9}$

The rate of LSCS in twin was statistically higher than that in singleton pregnancies (46\% vs $33.3 \%$, p value 0.01 ). Findings of present study agrees with other studies such as $42 \%$ in Obiechina et al, $43.1 \%$ in Muthihir JT and Pam VC. ${ }^{10,11}$ The increase in the use of caesarean section to deliver twin pregnancies were due to obstetric indications such as hypertensive disorder, malpresentations, PROM as observed in present study.

In this study, women with twin pregnancy had a 9-fold increase risk of preterm delivery as compared to singleton pregnancy. Current results are in agreement with Chiwanga ES et al who reported 6-fold increase risk of preterm delivery in twins. ${ }^{12}$ Garg $\mathrm{P}$ and Shebl ET O, Mazhar SB also reported similar risk of preterm. ${ }^{13-15}$ Preterm rate in present study was $62.7 \%$ which was higher than that reported by Muthihir JT et al, Qazi G, Sultana $\mathrm{M}$ et al, and Akaba GO et al. ${ }^{11,16-18}$ However, Rizwan $\mathrm{N}$ et al and in Hanumaiah et al showed higher rates of preterm delivery on their study (84\% and $74 \%$ respectively). ${ }^{7,19}$

Authors observed a 2.28-fold increased risk of hypertensive disorder in women with twin pregnancy. Current results were consistent with Akinboro A et al, Abasiattai AM, Olusanya Bo, Akaba GO et al, Chiwanga ES et al. ${ }^{6,8,12,18,20}$ Authors found that $15.3 \%$ women had hypertensive disorder which was lower than that reported by M Sultana et al, JY Foo et al, who found preeclampsia rate of $31 \%$ and $28 \%$ respectively. ${ }^{17,21}$ 
In current study mother with twin gestation had a 1.36fold increased risk of anaemia compared with singleton gestation. Findings of present study were in line with previous reports by Rizwan N et al, Qazi G, Sultan M et al. ${ }^{7,16,17}$ The rate of anaemia in present study was $8 \%$ which was lower as compare to previous studies. The reason for the lower rate of anaemia in the present study could be attributed to increased uptake of iron and folic acid supplements during antenatal care services.

There was 1.36 times higher risk of APH in twin pregnancies as compare to singleton group. Olusanya reported 1.2-fold increased risk in twin which was slightly lower than risk observed in present pregnancy and reported by Abasiattai AM and Sultana $\mathrm{M}$ et al. ${ }^{8,17,22}$ The difference in the risk of antepartum haemorrhage between studies could be explained by the difference in risk factors for antepartum haemorrhage between the studies populations.

In present study, the PPH rate was 2.75-fold higher in twins as compare to singleton group. Consistent with present study Musili et al also found significant increase in PPH in twin pregnancy as compare to singleton. ${ }^{4}$ The rate of $\mathrm{PPH}$ in present study $(8.7 \%)$ was lower than reported by Rizwan $\mathrm{N}$ et al and M Sultana et al $16 \%$ and $12.5 \%$ respectively. ${ }^{7,17}$

The risk of PROM in present study was 2.74 (24.7\%) times higher as compare to singleton pregnancy. Present result was consistent with Qazi who reported that $26 \%$ of women with twin pregnancy had PROM. ${ }^{16}$ Result of present study was in contrast with the result obtained by Akaba GO et al and Chiwanga ES and who reported lower rates of PROM. ${ }^{12,18}$

Risk of a twin pregnancy being delivered prematurely was about 2 times that of a singleton (OR 2.0073; 95\% CI: 1.0509-3.8342). Obiechina et al in their study observed the risk of a twin pregnancy being delivered prematurely was about 6.5 times that of a singleton (OR: 6.47, CI: $2.70-17.05) .{ }^{10}$ In present study, birth asphyxia and septicemia were seen in $5 \%$ and $2.7 \%$ twin babies respectively which were lower than that reported by Sultana $\mathrm{M}$ et al who observed birth asphyxia in $17 \%$ and septicemia in 5\% twin babies. ${ }^{17}$ Various observed morbidities were more in twins as compare to singleton babies.

Prematurity was the commonest cause of perinatal mortatlity in twins. Other causes are asphyxia, jaundice, respiratory distress, septicemia, unexplained and congenital disorder. Results of present study were comparable with study done by Sarojini et al. ${ }^{23}$

\section{CONCLUSION}

So, it is concluded that twin pregnancy is a great challenge to the concerned obstetricians. Complications associated with twin pregnancies cannot be prevented but can be detected early and controlled adequately by proper and prompt management. Perinatal deaths can be minimize by averting preterm births by combined measures like good rest, prophylactic cervical encerclage, short term tocolysis and administration of glucocorticoids. Timely diagnosis and treatment of nutritional anaemia and pre-eclampsia helps in preventing additional complications. Institutional delivery and provision of level 3 neonatal care will be key for reducing maternal and perinatal morbidity and mortality by which the millennium developmental goal 4 and 5 can be achieved.

\section{Funding: No funding sources}

Conflict of interest: None declared

Ethical approval: The study was approved by the Institutional Ethics Committee

\section{REFERENCES}

1. Pope RJ, Weintraub AY, Sheiner E. Vaginal delivery of vertex-nonvertex twins: a fading skill? Arch Gynecol Obstet. 2010;282:117-20.

2. Multiple Pregnancies: The management of twin and triplet pregnancies in the antenatal period. NICE Clinical Guidelines, No. 129. National Collaborating Centre for Women's and Children's Health (UK). London: RCOG Press; 2011.

3. Adamson H. Low birth weight in relation to maternal age and multiple pregnancies at Muhimbili National Hospital. DMSJ. 2006;14(2):55.

4. Musili FKJ. Multifoetal pregnancies at a maternity hospital in Nairobi. East Afr Med J. 2009;86(4):1625 .

5. Peter B. Prevalence of twin deliveries and perinatal outcomes in public hospitals in Dar es Salaam. M Med (Obstetrics and Gynaecology) Dissertation submitted to Muhimbili University of Health and Allied Sciences; 2012.

6. Olusanya BO. Perinatal outcomes of multiple births in southwest Nigeria. $\mathrm{J}$ Health Popul Nutr. 2011;29(6):639-47.

7. Rizwan N, abbasi RM, Mughal R. Maternal morbidity and perinatal outcome with twin pregnancy. J Ayub Med Coll Abbottbad. 2010;22(2):105-7.

8. Abasiattai AM, Umoiyoho AJ, Utuk NM, Shittu DG. Incidence and mode of delivery of twin pregnancies in Uyo, Nigeria. Niger Med J 2010; 51(4): 170-172.

9. Iyiola OA, Oyeyemi FB, Raheem UA, FO M. Frequency of twinning in Kwara State, North-Central Nigeria. The Egyptian J Med Hum Genet. 2013;14:29-35.

10. Obiechina NJ, Okolie VE, Eleje GU, Okechukwu $\mathrm{ZC}$, Anemeje OA. Twin versus singleton pregnancies: The Incidence, pregnancy complications and obstetric outcome in a Nigerian tertiary hospital. Int J Women Health. 2011;3:22730. 
11. Muthihir JT, Pam VC. Obstetric outcome of twin pregnancies in Jos, Nigeria. Nigerian J Clini Pract. 2007;10(1):15-18.

12. Chiwanga ES, Massenga G, Mlay P, Obure J, Mahande MJ. Maternal outcome in multiple versus singleton pregnancies in Northern Tanzania: A registry-based case control study. Asian Pacific J Reprod. 2014;3(1):46-52.

13. Garg P, Abdel-Latif ME, Bolisetty S, Bajuk B, Vincent $T$, Lui K. Perinatal characterstics and outcome of preterm singleton, twin and triplet infants in NSW and the Act, Australia (1994-2005). Arch Dis Child-Fetal Neonatal Ed. 2010;95(1):F20-F24.

14. Shebl O ET, Sir A, Sommergruber M, Tews G. The role of mode of conception in the outcome of twin pregnancies. Minerva Ginecol. 2009;61(2):141-52.

15. Mazhar SBPA, Mahmud G. Maternal and perinatal complication in multiple versus singleton pregnancies: a prospective two years study. J Pak Med Assoc. 2002;52(4):143-7.

16. Qazi G. Obstetric and perinatal outcome of multiple pregnancy. J Coll Physicians Surg Pak. 2011;21(3):142-5.

17. Sultana M, Khatun S, Ara R, Saha AK, Akhter P, Shah ABS. Maternal and perinatal outcome of twin pregnancy in a tertiary hospital. Ibrahim Card Med J. 2011;1(2):35-9.

18. Akaba GO, Agida TE, Onafowokan O, Offiong RA, Adewole ND. Review of twin pregnancies in a tertiary hospital in Abuja, Nigeria. J Health Popul Nutr. 2013;31(2):272-7.

19. Hanumaiah I, Shivanand DR, Visweshwaraiah KG, Hoolageri MS. Perinatal outcome of twin pregnancies at a tertiary care centre, South India. Int J Biol Med Res. 2013;4(1):2683-5.

20. Akinboro A, Azeez MA, Bakare AA. Frequency of twinning in southwest Nigeria. Indian J Hum Genet. 2008;14(2):41-7.

21. Foo JY, Mangos GJ, Brown MA. Characteristics of hypertensive disorders in twin versus singleton pregnancies. Pregnancy Hypertens. 2013;3(1):3-9.

22. Olusanya BO, Solanke OA: Perinatal correlates of delayed childbearing in a developing country. Arch Gynecol Obstet. 2012;285(4):951.

23. Sarojini R, Bhanu BT, Kavyashree KS. Evaluation of perinatal outcome in twin pregnancy at tertiary care centre. Int J Reprod Contracept Obstet Gynecol. 2014;3(4):1015-21.

Cite this article as: Gupta D, Mital P, Meena BS, Benwal D, Saumya, Singhal S et al. Comparative assessment of fetomaternal outcome in twin pregnancy with singleton pregnancy at tertiary care centre. Int J Reprod Contracept Obstet Gynecol 2017;6:2395-2400. 